\title{
Dampak Perusahaan Perkebunan Kelapa Sawit Terhadap Perubahan Kebudayaan Masyarakat Desa Pasar Minggu Kecamatan Maro Sebo Kabupaten Muaro Jambi Provinsi Jambi
}

\author{
${ }^{1}$ Leonik, ${ }^{2}$ Kafsul Anwar US \\ 1-2 Fakultas Ekonomi dan Bisnis, Universitas Negeri Sultan Thaha Shaifuddin Jambi
}

\author{
Article history \\ Received: 19-03-2021 \\ Revised: $22-04-2021$ \\ Accepted: 19-05-2021 \\ *Corresponding Author: \\ Leonik, \\ Kafsul Anwar US, \\ Fakultas Ekonomi dan \\ Bisnis, \\ Universitas Negeri Sultan \\ Thaha Shaifuddin Jambi \\ Email: \\ Leonibe66@gmail.com
}

\begin{abstract}
Abstrak: Penelitian ini bertujuan untuk mendeskripsikan perubahan kebudayaan yang terjadi di daerah penelitian terkait dengan keberadaan perusahaan perkebunan kelapa sawit di Desa Pasar Minggu. Penentuan lokasi penelitian dilakukan secara sengaja (Purpossive).Pengumpulan data dalam penelitian ini terdiri dari data primer dan data sekunder.Untuk mendapatkan data yang lebih mendalam dilakukan wawancara mendalam (In-depht interview) serta menggunakan teknik bola salju (Snowball).Berdasarkan metode yang digunakan, hasil penelitian menunjukkan bahwa terjadinya perubahan kebudayaan masyarakat Desa Pasar Minggu Kecamatan Maro Sebo Kabupaten Muaro Jambi Provinsi Jambi. Perubahan itu di mulai dari perubahan mata pencaharian masyarakat yang kemudian proses inovasi, difusi, dan integrasi mempengaruhi unsur-unsur kebudayaan masyarakat di Desa Pasar Minggu yaitu sistem peralatan hidup,sistem kepercayaan, organisasi sosial, kesenian,bahasa, dan sistem pengetahuan.Keberadaan perusahaan perkebunan kelapa sawit PT. Batang Hari Sawit Sejahtera (BSS), Kertapersada di Desa Pasar Minggu juga menimbulkan dampak terhadap masyarakat Desa Pasar minggu, baik itu dampak positif maupun dampak negatif. Dampak positif seperti kesempatan kerja, peluang berusaha, peningkatan pendapatan masyarakat, bantuan pendidikan, serta betambah dan berkembangnya organisasi di masyarakat. Sedangkan dampak negatifnya persaingan untuk mendapatkan pekerjaan yang lebih layak di perusahaan antara masyarakat Desa Pasar Minggu dengan pendatang. Tidak hanya itu, mudahnya arus informasi masuk dan bertambahnya penduduk menjadikan masyarakat yang heterogen sehingga pengaruh narkoba dan sabu-sabu sangat mudah mempengaruhi dan akhirnya digunakan masyarakat terutama Pemuda Pasar Minggu.

Kata Kunci : Dampak Perubahan Kebudayaan,Unsur-Unsur Kebudayaan.
\end{abstract}

\section{PENDAHULUAN}

Kegiatan pembangunan perekonomian merupakan proses yang berkesinambungan dengan tujuan akhir untuk meningkatkan kesejahteraan masyarakat. Oleh karena itu, strategi pembangunan haruslah dapat memacu pertumbuhan ekonomi serta meningkatkan kualitas sumber daya manusia.Pertanian masih menjadi tumpuan hidup bagi masyarakat yang didominasi oleh dua subsektor yaitu tanaman pangan dan perkebunan.

Di Indonesia sektor pertanian masih di andalkan bagi pembangunan nasional dan dapat mendorong sektor industri yang berkembang pada saat ini. Perkembangan pertanian diharapkan mampu memberikan kontribusi nyata bagi pembangunan dan masyarakat.Sektor tanaman perkebunan merupakan bagian terpenting di Provinsi Jambi, hal ini ditunjukkan dengan fakta bahwa komoditi ini dapat menyumbang Pendapatan Domestik Regional Bruto (PDRB) Provinsi Jambi yang signifikan setiap Tahunnya.Oleh karena itu Pemerintah Provinsi Jambi mengandalkan komoditi ini sebagai andalan pertumbuhan ekonomi yang mampu mengangkat taraf hidup dan dapat mensejahterakan masyarakat(Badan Pusat Statistik,(011). 
Kelapa sawit merupakan komoditas perkebunan unggulan baru yang mulai dikembangkan secara besar-besaran di Provinsi Jambi pada pertengahan 1990-an. Dewasa ini, hampir semua Kabupaten kecuali Kabupaten Kerinci di kembangkan perkebunan kelapa sawit melalui berbagai pola pengembangannya, baik dalam bentuk Perkebunan Besar Swasta (PBS), Perkebunan Besar Negara (PBN), perkebunan rakyat plasma ataupun dalam bentuk swadaya murni oleh petani perkebunan.

Walaupun merupakan komoditi yang baru dikembangakan, namun perkebunan kelapa sawit sudah menjadi basis ekonomi masyarakat di provinsi Jambi.Perkebunan kelapa sawit di Provinsi Jambi tersebar diseluruh wilayah Kabupaten yang ada di Provinsi Jambi.Produktifitas rata-rata kelapa sawit di Provinsi Jambi mencapai 3.417 ton/ha dengan luas areal perkebunan kelapa sawit 532.293 ha dan produksi sebesar 1.426.081 ton, serta dapat dilihat juga bahwa Kabupaten Muaro Jambi memiliki areal lahan kelapa sawit terluas dibandingkan dengan Kabupaten lainya yang ada di Provinsi Jambi yang mencapai 130.260 ha, dengan produksi sebanyak 334.020 ton dan sebagian besar luas areal perkebunan kelapa sawit di Kabupaten Muaro Jambi di miliki oleh perusahaan perkebunan Swasta (Dinas Perkebunan Provinsi Jambi, 2011).Dalam rangka usaha untuk mewujudkan tujuan Nasional sebagaimana termaksud dalam pembukaan Undang-undang Dasar 1945, maka pemerintah mengeluarkan UU Nomor.18 tahun 2004 tentang perkebunan dimana tujuan adanya perkebunan secara umum adalah untuk mensejahterakan masyarakat,Kemudian di tindak lanjuti dengan adanya Peraturan Menteri Pertanian No.26/Permentan/OT.140/2/2007 tentang pedoman perizinan usaha perkebunan pasal 34 point g perusahaan perkebunan memiliki kewajiban menumbuhkan dan memberdayakan masyarakat setempat dan pasal 11 perusahaan perkebunan berkewajiban membangun kebun untuk masyarakat sekitar paling rendah seluas $20 \%$ dari total luas areal kebun yang diusahakan perkebunan bersamaan dengan pembangunan kebun yang diusahakan oleh perusahaan melalui pola kredit, hibah atau bagi hasil.

\section{METODE PENELITIAN}

Penelitian ini dilaksanakan di Desa Pasar Minggu Kecamatan Maro Sebo Kabupaten Muaro Jambi Provinsi jambi. Pemilihan lokasi penelitian ini dilakukan dengan sengaja (purposive). In depth interview dilakukan untuk memperoleh data dan informasi dari informan yang di pandu oleh panduan wawancara. Penelitian ini juga menggunakan teknik Snowball.

Teknik ini digunakan ketika informan merekomendasikan untuk wewawancarai informan lainya yang dinilai dapat memberikan informasi tambahan dan informan yang dimaksud memiliki data/informasi yang lebih kuat dan akurat.Miles dan Huberman(2009) menganggap bahwa analisis terdiri dari tiga alur kegiatan yang terjadi secara bersamaan, yaitu: reduksi data, penyajian data, dan penarikan kesimpulan/verifikasi. Penelitian ini dilaksanakan selama satu bulan. Dalam penelitian ini yang menjadi informan adalah masyarakat yang mengetahui sejarah Desa Pasar Minggu, kemudian mengetahui kondisi masyarakat sebelum dan setelah berdirinya perusahaan perkebunan kelapa sawit PT Batang Hari Sawit Sejahtera(BSS).Pemilihan informan menggunakan metode urposive Sampling dan Snowball (Sugiyono,2009). Informan dalam penelitian ini ialah sekertaris desa, ketua BPD, kaur pemerintahan, tokoh masyarakat, karyawan perkebunan, buruh perkebunan dan petani di Desa Pasar Minggu. Dalam penelitian ini, perubahan kebudayaan yang di lihat ialah perubahan unsur-unsur kebudayaan masyarakat.

\section{HASIL DAN PEMBAHASAN}


Hasil wawancara terhadap sembilan informan mengenai dampak perusahaan perkebunan kelapa sawit terhadap perubahan kebudayaan masyarakat Pasar Minggu Kecamatan Maro Sebo Kabupaten Muaro Jambi Provinsi Jambi diketahui hasilnya, sehingga dapat di pelajari kondisi sebelum dan sesudah adanya perusahaan perkebunan kelapa sawit secara lengkap hasil tabulasi mengenai tujuh aspek yang di amati terlampir. Uraian dari masing-masing aspek pengamatan di sajikan sebagai berikut :

Sistem Peralatan Hidup (teknologi) Perubahan kebudayaan masyarakat jauh lebih cepat dari pada alam. Sedangkan menurut Soekanto (1990) hasil karya masyarakat melahirkan teknologi atau kebudayaan kebendaan yang mempunyai kegunanaan utama di dalam melindungi masyarakat terhadap lingkungan. Sistem peralatan hidupatau teknologi masyarakat mebelum berdirinya perusahaan masih sangat sederhana dan mengandalkan tenaga manusia sebagian besarnya. Pada saat itu masyarakat sangat susah untuk kemudian mengubah perekonomiannya karena hasil dari panen juga sangat tergantung dengan kondisi alam. Seperti alat untuk membersihkan lahan dan mengolah tanah,alat untuk memanen, serta alat untuk pengangkutan hasil panen.Dari hasil penelitian,Sistem peralatan hidup masyarakat setelah beridirinya perusahaan sangat bermacam-macam.Hal ini juga di pengaruhi oleh komoditi yang ditanam masyarakat ikut berubah, karena sebagian besar masyarakat menanam tanaman kelapa sawit. Ada yang masih menggunakan tenaga manusia namun relatif kecil dan sebagian besar masyarakat menggunakan teknologi dalam sistem peralatan hidupnya.

Proses peralihan peralatan hidup masyarakat dari penggunaan alat-alat pertanian sederhana menuju alat-alat pertanian yang berteknologi dan penerimaan masyarakat atas teknologi tersebut. Contohnya masyarakat dahulu menggunakan parang untuk membersihkan lahan yang akan ditanami sekarang masyarakat menggunakan mesinrumput untuk membersihkan lahan.

\section{Sistem Mata Pencaharian}

Menurut Siswanto (1989) masyarakat pedesaan adalah masyarakat yang hidup di desa yang bermata pencaharian di bidang pertanian, perikanan, peternakan, perkebunan dan sebagainya.Masyarakat Desa Pasar Minggu merupakan masyarakat yang berasal dari daerah jawa yang mengikuti transmigrasi. Dalam masyarakat akan terjadi proses interaksi, interaksi sosial terjadi karena pihak-pihak itu mempunyai kebutuhan atau kepentingan yang tidak dapat dipenuhi sendiri sehingga pihak-pihak yang bersangkutan tersebut perlu saling berhubungan antara satu sama lain atau saling berinteraksi, baik secara fisik maupun intelektual (Muhammad, 2008).

Dari hasil penelitian, Berdirinya perkebunan kelapa sawit membawa perubahan mata pencaharian bagi masyarakat Desa Pasar Minggu yang dulunya hanya berladang dengan tanaman pangan dan hortikultura sekarang ada yang bekerja di perusahaan perkebunan sebagai karyawan perusahaan, mandor, dan tenaga buruh harian misalnya bongkar muat buah sawit, pemupukan, mendodos dan membersihkan rumput di perusahaan perkebunan, sebagian masyarakat ada yang mempunyai kebun sawit milik pribadi maupun sawit plasma dari perusahaan. Tidak hanya itu, Desa Paasar Minggu menjadi tujuan para pencari kerja, baik pencari kerja di daerah setempat maupun pencari kerja dari luar daerah serta ada tenaga kerja yang di bawa oleh perusahaan itu sendiri, dengan jumlah penduduk yang padat ada masyarakat yang menggunakan kesempatan ini 
dengan membuka peluang usaha baru seperti membuka warung sembako, rumah makan, bengkel, pedagang maupun toko bangunan. Masyarakat mulai berfikir bagaimana mendapat pengahasilan lain selain bertani dan bekerja di perusahaan yaitu dengan membuka layanan jasa (warung sembako, kios pulsa, dan bengkel motor), beralihnya dari bertani ke berkebun.

\section{Organisasi Sosial Keberadaan}

Perusahaan perkebunan kelapa sawit PT. Ricky Kurniawan Kertapersada di Desa Mekar Sari meningkatkan jumlah penduduk yang berasal baik dari dalam daerah maupun luar daerah Provinsi Jambi, semua masyarakat hidup rukun berdampingan dalam suatu komunitas masyarakat desa. Datangnya masyarakat pendatang yang menetap di Desa Mekar Sari memberikan pemikiran untuk pembangunan desa, salah satu bentuk pemikiran itu adalah dalam bidang organisasi sosial.

Menurut Soekanto (1990) Bertambah atau berkurangnya penduduk menyebabkan perubahan dalam struktur masyarakat, terutama lembaga atau organisasi kemasyarakatan. Organisasi kemasyarakatana tau organisasi sosial berfungsi sebagai pedoman masyarakat dalam bertingkah laku dalam menghadapi masalah dalam masyarakat, menjaga keutuhan masyarakat, dan sistem pengendalian sosial di masyarakat ( Soekanto, 2010). Sebelum ada perusahaan hanya ada tiga organisasi sosial yaitu kelompok pencapir, karang taruna dan kelompok tani. setelah adanya perusahaan perkebunan kelapa sawit PT. Ricky Kurniawan kertapersada organisasi sosial di desa ini mengalami perkembangan, hingga sampai saat ini ada lima yang bertahan yaitu karang taruna, yasinan,

Persatuan santunan orang cacat dan yatim piatu, PKK, dan kelompok tani, hal tersebut membuktikan adanya perubahan organisasi sosial setelah adanya perusahaan. Ada organisasi yang bertahan dan ada organisasi baru.

\section{Kesenian}

Menurut antropolog C. Kluckhohn dalam Soekanto (2010), Penggunaan kesenian merupakan salah satu unsur kebudayaan yang digunakan dalam masyarakat. Karena kesenian dianggap sebuah tradisi dari nenek moyang yang mesti diteruskan. Dari hasil penelitian, Adanya perusahaan perkebunan PT. Ricky Kurniawan Kertapersada memberikan dampak kepada kesenian masyarakat Desa Mekar Sari. Kesenian di masyarakat Desa Mekar Sari dahulu relatif sama dengan masyarakat jawa karena masyarakat Desa Mekar Sari merupakan masyarakat transmigrasi yang sebagian besar berasal dari Jawa dan mulai menerapkan kembali di Desa Mekar Sari. Kesenian-kesenian yang ada di masyarakat sebelum berdirinya perusahaan yaitu wayang kulit, ludruk, kuda kepang, dan PSHT. Kesenian-kesenian yang ada di masyarakat setelah berdirinya perusahaan yaitu wayang kulit, organ tunggal, kompangan, dan PSHT. Sebuah kebudayaanmendapat pengaruh dari budaya lain, yang hal tersebut kemudian memicu perubahan kebudayaan dalam masyarakat yang "menerima". unsur-unsur budaya tersebut ( Martono, 2012).

\section{Bahasa}

Bahasa dapat berubah karena adanya perubahan menyangkut mengenai bahasa 
sebagai kode, dimana sesuai dengan sifatnya yang dinamis, dan sebagai akibat persentuhan dengan kode-kode lain. Pergeseran bahasa menyangkut masalah mobilitas penuturan, dimana sebagai akibat dari perpindahan penutur atau para penutur itu sendiri yang menyebabkan pergeseran itu. Sedangkan pemertahanan bahasa lebih menyangkut masalah sikap atau penilaian terhadap suatu bahasa, untuk tetap menggunakan bahasa tersebut di tengah-tengah bahasa-bahasa lain.

Menurut Soekanto (2010) percampuran atau akulturasi terjadi bila suatu kelompok manusia dengan suatu kebudayaan tertentu dihadapkan pada unsur-unsur suatu kebudayaan asing yang berbeda sedemikian rupa sehingga unsur-unsur kebudayaan asing lambat laun diterima dan diolah ke dalam kebudayaan sendiri, tanpa menyebabkan hilangnya kebudayaan itu sendiri.

Gillin dan Gillin dalamsoekanto (2010) mengatakan interaksi sosial merupakan hubungan-hubungan sosial yang dinamis yang menyangkut hubungan antara orangperorangan, antara kelompok-kelompok manusia, maupun antara orang-perorangan dengan kelompok manusia. Dalam berinteraksi antar masyarakat menggunakan bahasa campuran (Jawa, Indonesia,dan Jambi) namun ketika mereka bertemu dengan masyarakat yang berasal dari satu etnis maka mereka menggunakan bahasa daerah mereka masing-masing walaupun berjumpa ditempat umum. Walaupun tidak terjadi perubahan bahasa dalam komunikasi masyarakat Desa Pasar Minggu namun kehadiran perusahaan perkebunan PT. Batang Hari Sawit Sejahaterah (BSS) menciptakan keanekaragaman kata daerah, karena asal daerah mereka yang berbeda pula sehingga sedikit ataupun banyak masyarakat mempunyai kosa kata daerah lain terutama bahasa yang berasal dari daerah Jawa. Contoh kata dalam bahasa Jawa yang sering digunakan adalah "apik, okeh, nggeh, monggo".

\section{Sistem Pengetahuan}

Masyarakat Desa Pasar Minggu yang merupakan daerah transmigrasi yang kemudian sebagian besar masyarakat rata-rata hanya berpendidikan setara sekolah dasar (SD) dan bahkan ada yang tidak tamat sekolah dasar (SD), hal tersebut pasti akan mempengaruhi masyarakat dalam berusaha tani, bertindak, dan mengambil keputusan dalam pilihan berusahatani dan mengambil keputusan dalam kehidupan yang akan datang. Menurut Martono (2012) pendidikan merupakan salah satu institusi penting dalam proses perubahan pada suatu masyarakat. Masyarakat yang memiliki pendidikan yang maju tentu saja dapat mempercepat perubahan kebudayaan dalam masyarakat.

Dari hasil penelitian, Sebelum berdirnya perusahaan perkebunan kelapa sawit PT. Batang Hari Sawit Sejahterah masyarakat hanya berusahatani. Pengetahuan masyarakat akan mempengaruhi apa pilihan masyarakat dalam berusahatani dan cara berusahataninya. Dahulu masyarakat hanya berusahatani tanaman pangan seperti jagung, padi dan umbi jalar. Hal ini bukan hanya karena masyarakat dahulunya di Jawa hanya menanam padi sawah namun juga karena pendidikan masyarakat yang juga hanya tamat sekolah dasar(SD) dan hanya sebagian kecil yang sekolah menengah pertama(SMP) sehingga mempengaruhi mereka dalam berusahatani. Masyarakat yang pada umumnya hanya berusahatani tanaman pangan sebagian proses penanaman sampai penen hampir semua di kerjakan oleh tenaga manusia dan menggunakan pengalaman-pengalaman dalam berusahati sebelumnya. Contoh dalam penanaman jagung, dahulu masyarakat menggunakan benih turunan yaitu benih yang di 
buat dengan mengambil jagung-jagung yang bagus menurut petani. Hal tersebut sesuai dengan pendapat Dewey dalam Martono(2012) yang mengatakan bahwa pendidikan secara lebih luas sebagai organisasi pengalaman hidup, serta pembentukan kembali pengalaman hidup.

\section{Dampak Terhadap Perubahan Sosial Dimensi Kultural Masyarakat}

Menurut Martono (2012), Perubahan senantiasa mengandung dampak negatif maupun positif.Untuk itu, dalam merespons perubahan diperlukan kearifan dan pemahaman yang mendalam mengenai nilai, arah program, dan strategi yang sesuai dengan sifat dasar perubahan itu sendiri. Perkebunan kelapa sawit, yang dalam proses pelaksanaanya mengubah ekosistem hutan menjadi ekosistem monokultur, tanpa dapat dihindari menciptakan kedua jenis dampak tersebut. Apalagi jika disekitar kawasan kebun berdiam penduduk dalam jumlah cukup besar, maka hampir dapat dipastikan kehidupan mereka akan berpengaruh baik secara ekonomi, sosial, maupun budaya.

\section{Dampak Positif}

Kesempatan Kerja Keberadaan PT. Makin Group membawa dampak positif dalam perekonomian warga di dalam dan sekitar kawasan perkebunan. Banyak warga Desa Pasar Minggu ikut bekerja di perusahaan baik sebagai buruh harian lepas maupun sebagai karyawan tetap. Sebagian warga Desa Pasar Minggu yang tidak bekerja di perusahaan mereka bekerja di kebun sendiri yaitu kebun kelapa sawit maupun tanaman pangan. Ketidakpasti an tersedianya tenaga kerja lokal membuat pihak perusahaan mendatangkan tenaga kerja dari luar Desa Pasar Minggu bahkan dari jawa dan daerah lainnya.

\section{Peluang Berusaha}

Keberadaan perusahaan perkebunan kelapa sawit PT. Batang Hari Sawit Sejahtera Kertapersada memberikan peluang kepada masyarakat setempat untuk berusaha. Bentuk usaha yang sudah ada saat ini adalah warung sembako, rumah makan, dan bengkel motor. Terbukanya peluang usaha, tentunya akan mengurangi jumlah penggangguran baik diluar maupun sekitar kawasan perkebunan.

\section{Peningkatan Pendapatan Masyarakat Desa Pasar Minggu}

Keberadaan kegiatan perusahaan perkebunan kelapa sawit PT. Batang Hari Sawit Sejahterah baik kegiatan perkebunan dan pengolahan kelapa sawit telah memanfatkan sumber daya lokal, seperti tenaga kerja, maupun keperluan sehari-hari seperti sembako yang di beli dari usaha warung masyarakat Desa Pasar Minggu. Pendapatan masyarakat Desa Pasar Minggu akan meningkat secara bertahap berkat kesempatan kerja dan peluang usaha dari perusahaan. Selain itu,berkat bekerja di perusahaan masyarakat Desa Pasar Minggu bisa menabung karena keperluan sehari-hari dapat di penuhi dari kebun sendiri sehingga hasil dari bekerja di tabung untuk keperluan-keperluan primer, kebutuhan tidak terduga dan kebutuhan di masa depan.

\section{Bertambahnya dan berkembangnya Organisasi Sosial}

Meskipun terdapat banyak faktor yang mempengaruhi perubahan organisasi dan 
struktur sosial masyarakat, perkembangan wilayah Desa Pasar Minggu sehingga akses informasi mudah masuk inilah yang dominan menyebabkan terjadinya perubahan organisasi dan struktur sosial di masyarakat. Selain itu, harus diakui bahwa perkembangan di sekitar lokasi PT.Batang Sawit Sawit Sejahterah tidak hanya disebabkan oleh keberadaan PT.Batang Hari Sawit Sejahterah saja, tetapi perbaikan akses jalan perusahaan yang menghubungkan perusahaan dengan desa. Perkembangan organisasi di Desa Pasar Minggu seolah telah menjadi kebutuhan sebagai tempat menyalurkan ide kreatif untuk menunjang sumber daya manusia terutama pemberdayaan generasi muda dan mempererat tali silaturahmi sesama masyarakat. Desa Pasar Minggu sebagai tempat para pencari kerja yang datang dari berbagai daerah sehingga pengaruh negatif pun dari mereka yang datang dapat di cegah dengan organisasi yang ada di Desa Pasar Minggu.

\section{Dampak Negatif}

Berdirinya perusahaan perkebunan kelapa sawit PT. Batang Hari Sawit Sejahterah Kertapersada di Desa Pasar Minggu selain memberikan dampak positif, masyarakat sekitar juga merasakan dampak negatifnya, Dari penelitian yang dilakukan bahwa berdirinya perusahaan pekebunan kelapa sawit PT. Batang Hari Sawit Sejahterah Kertapersada memberikan dampak positif yang lebih besar dibandingkan dengan dampak negatifnya. Dampak negatif yang tejadi pada perubahan kebudayaan terjadi pada persaingan mendapatkan pekerjaan. Masyarakat yang bekerja di perusahaan perkebunan sebagian besar bekerja sebagai buruh harian dan hanya sebagian kecil yang menjadi karyawan tetap.Selain itu, dampak negatif terjadi pada organisasi sosial. Organisasi yang terus berkembang di Desa Pasar Minggu membuat persaingan dalam menduduki sebuah jabatan atau kekuasaan di setiap organisasi yang ada. Terkadang organisasi sosial menjadi sasaran pendekatan politik bagi elite politik untuk mendapatkan kekuasaan selanjtnya bukan di bangun atas kesadaran untuk membangun desa.

\section{KESIMPULAN}

Berdasarkan hasil penelitian keberadaan perusahaan perkebunan kelapa sawit PT. Batang hari sawit sejahterah Desa pasar minggu menyebabkan perubahan kebudayaan masyarakat.

Perubahan itu di mulai dari perubahan mata pencaharian masyarakat yang kemudian proses-proses inovasi, difusi, dan integrasi mempengaruhi unsur-unsur kebudayaan masyarakat di Desa pasar minggu yaitu sistem peralatan hidup, sistem mata pencaharian masyarakat, sistem kepercayaan, organisasi sosial, kesenian, bahasa, dan sistem pengetahuan. Selain itu, adanya perusahaan perkebunan kelapa sawit PT. Batang hari sawit sejahterah di Desa Pasar Minggu membuat harus informasi sangat mudah masuk sehingga merubah pola pikir masyarakat yang kemudian merubah gaya hidup masyarakat.Keberadaan perusahaan perkebunan kelapa sawit

PT. Ricky Batang Hari Sawit Sejahterah Desa Pasar Minggu juga menimbulkan dampak terhadap masyarakat Desa Pasar minggu, baik itu dampak positif maupun dampak negatif. Dampak positif seperti kesempatan kerja, peluang berusaha, peningkatan pendapatan masyarakat, bantuan pendidikan, serta bertambah dan berkembangnya organisasi di masyarakat. Sedangkan dampak negatifnya persaingan untuk mendapatkan pekerjaan yang lebih layak di perusahaan antara masyarakat Desa Pasar Minggu dengan pendatang. Tidak hanya itu,mudahnya arus informasi masuk dan 
bertambahnya penduduk menjadikan masyarakat yang heterogen sehingga pengaruh narkoba dan sabu-sabu sangat mudah mempengaruhi dan akhirnya digunakan masyarakat terutama pemuda DesaPasar Minggu

\section{DAFTAR PUSTAKA}

Badan Pusat Statistik. 2011. Jambi Dalam Angka. BPS Provinsi Jambi

Dinas Perkebunan Provinsi Jambi. 2011. Statistik Perkebunan 2011. Jambi

Haryanto Dany, Nugrohadi Edwi. 2011. Pengantar Sosiologi Dasar. Prestasi Pustakaraya. Jakarta Martono

Nanang. 2012. Sosiologi Perubahan Sosial. Raja Grafindo Persada. Jakarta

Miles, MB., Huberman, AM. 2009. Analisis Data Kualitatif Buku Sumber Tentang Metode-metode Baru (diterjemahkan oleh Tjetjep Rohendi Rohidi). UIP.

Muhammad, A. 2008. Ilmu Sosial Budaya Dasar. Citra Aditya Bakti. Bandung

Siswanto. 1989. Ilmu So sial Dasar. IKIP Malang. Malang

Soekanto Soerjono. 1990. Sosiologi Suatu Pengantar. Raja Grafindo Persada. Jakarta

Soekanto Soerjono. 2010. Sosiologi Suatu Pengantar. Raja Grafindo Persada. Jakarta

Sugiyono. 2009. Metode Penelitian Kuantitatif Kualitatif dan R\&D. Alfabeta jambi 